\title{
The Main Factors in the Development of Modern Ukrainian Language Education in the Southern Regions of Ukraine
}

\author{
Sushko Volodimir \\ ORCID https://orcid.org/0000-0001-6344-7318 \\ Postgraduate at the Department of Pedagogy and Education \\ Management Municipal Higher Educational Institution «Kherson Academy of \\ Continuing Education» of Kherson Region (Ukraine, Kherson)
}

\begin{abstract}
The article considers the development of modern Ukrainian-language education in the Southern region of Ukraine. Presented such areas of Ukrainian society as socio-political, socio-economic, and socio-cultural, identified the main factors in the development of Ukrainian-language education in the current implementation of state national and language policy, in particular of education. Among such factors are the formation of a selfsufficient citizen-patriot of Ukraine, the improvement of the communicative competencies of the language personality; development of information and communication technologies, development, strengthening and improvement of material and technical base of educational process and educational branch; polyethnicity of the Ukrainian state, multicultural educational environment, development of Ukrainian language didactics, development of speech and communicative competencies of the individual, his language culture, training of qualified scientific and pedagogical workers. To conclude the development of Ukrainian-language education is directly influenced by all the above-mentioned factors that enable the achievement and implementation of one of the main objectives of the national language and educational policy of Ukraine, - improving the communicative competencies of language personality.

Key words: bilingualism, communicative competence, language personality, language policy, national policy, polyethnicity, education reform, educational policy, Ukrainian language education.
\end{abstract}

Актуальність дослідження. Реформування сучасної освіти в Україні сьогодні є відгуком на внутрішньополітичні виклики в державі та на динамічну трансформацію глобалізованого світу. Сьогодні в країні відбувається формування нової парадигми національної системи освіти, осучаснення їі концепції, структури і змісту. Освіта в Україні як соціальне явище, що має свою концепцію, структуру, зміст, напрями, безпосередньо пов'язане з іншими складовими державної політики, зокрема мовної.

У сучасному українському суспільстві залишається відкритим питання вироблення чіткої національної мовної політики. Однією 3 нагальних потреб сьогодення $є$ створення умов для збереження й розвитку української мови та мов національних меншин [19, с. 232].

Україна є багатонаціональною державою. Грунтуючись на ідеологічних засадах, відповідно до чинного суспільно-політичного ладу, уряд проводить мовну політику таким чином, щоб урахувати й регіональні фактори суспільних відносин. До таких 
факторів належать дво- або багатомовність, своєрідність національного складу і міжнаціональних відносин, що історично склалися, роль окремих мов та їх носіїв у громадському житті $[3$, с. $649 ; 13 ; 14 ; 20]$.

Проблеми розвитку освітньої галузі, iï реформування, а також питання україномовної освіти досліджували науковці: Л. Березівська, В. Борисенко, І. Жорова, О. Кучерук, Т. Окуневич, В. Олексенко, М. Пентилюк, В. Спірін, О. Телегуз та ін.

Право на освіту є одним з основних, гарантованих Конституцією України, соціально-культурних прав громадян нашої держави, закріплене законом України «Про освіту», і забезпечується можливістю навчання в школі рідною мовою [2,с. 267].

Південний регіон України є багатонаціональним за своїм складом населення. Державною мовою в нашій країні $є$ українська, і вона не може існувати поза освітнім процесом, що регламентовано чинним законодавством.

Таким чином, питання розвитку сучасної україномовної освіти в Південному регіоні України на сьогодні є актуальним.

Метою статті $\epsilon$ визначення основних чинників розвитку сучасної україномовної освіти в Південному регіоні України.

Виклад основного матеріалу. Українська літературна мова як державна і як рідна в закладах освіти не тільки вивчається, але й нею викладають навчальні дисципліни відповідно до чинного законодавства й освітньої мети. Викладання українською мовою та її вивчення здійснюється у закладах освіти, поза їх межами, дистанційно, а також за допомогою використання різних методів, вербальних і невербальних засобів. У нашій статті поняття «україномовна освіта» визначається саме в такому аспекті. Україномовний освітній процес безпосередньо залежить від рівня матеріально-технічної бази закладу, учасників процесу та технічного забезпечення конкретного здобувача освіти.

Україномовна освіта є явищем соціальним. Кожне явище, і кожен процес зумовлюються певними чинниками.

Одним із чинників розвитку україномовної освіти є урядова мовна політика, головним завданням якої є розв'язання мовних проблем у суспільстві, сприяння ефективному функціонуванню мови в різних сферах їі застосування [19, с. 231]. 
Освіта сьогодні є одним із засобів розвитку особистості загалом і суспільства в цілому. Майбутнє соціуму залежить також і від рівня освіти, від іiї здатності динамічно реагувати на виклики й перетворення глобалізованого світу, на іiі відтворюваність, здатність впливати на суспільне життя, «адаптуючись до нових потреб суспільства i водночас активно впливаючи на його стан, визначаючи власне і самі потреби» [18].

Спираючись на вищезазначену думку, ми можемо зауважити, що однією із потреб сучасного українського суспільства $є$ забезпечення якості освіти, зокрема україномовної, на рівні світовому, тобто іiі удосконалення як духовної національної цінності, так і сутнісного її наповнення [1, с. 4].

Духовність не є суто абстрактною категорією. Вона формується й розвивається під впливом конкретних і відповідних дій. Так, наприклад, В. Олексенко зазначає, що рідна мова є надзвичайно важливим чинником формування духовного світу людини. Мову як духовне багатство треба вивчати та розвивати. Володіння мовою формує розуміння й усвідомлення необхідності мислити й висловлювати свої думки, залучає до «духовної культури народу, засвоєння традицій розвитку мови, iї функціонування у суспільстві» [11, с. 189].

Як бачимо, одним із засобів формування та розвитку духовних національних цінностей, духовного світу людини є вивчення рідної мови, зокрема украӥнської. Це є щее одним із важливих чинників розвитку украӥномовної освіти.

Чинником розвитку україномовної освіти, іiі гуманітарної складової, що є індикатором культурно-освітнього рівня суспільства [4, с. 89], відповідно до мети національно-патріотичного виховання в сучасній системі освіти України, $\epsilon$ також становлення самодостатнього громадянина-патріота Украӥни, гуманіста $i$ демократа, готового до виконання громадянських $i$ конституиійних обов'язків, до успадкування духовних і культурних надбань українського народу, досягнення високої культури взаємин, що сприяє єднанню українського народу, зміцненню соціальноекономічних, духовних, культурних основ розвитку українського суспільства i держави [8].

О. Спірін зауважує, що сучасне суспільство - це суспільство нового типу, глобальне суспільство, суспільство знань, які набуваються насамперед завдяки доступу до інформації, постають основною умовою благополуччя людини і держави; 
нове глобальне суспільство «сприяє взаємному проникненню культур, однак відкриває кожній культурі нові можливості для самореалізації» [18].

Отже, науково-технічний прогрес, що зумовив розвиток інформаційнокомунікативних технологій є ще одним чинником розвитку сучасної україномовної освіти.

Інформація сьогодні як товар $€$ однією 3 умов економічного зростання української держави, що може поліпшити та зміцнити матеріально-технічну базу як освітнього процесу (комп’ютеризація, оснащення інтерактивними дошками, нетбуками, вільний доступ до інтернету), так і технічного оснащення здобувачів освіти (різного виду гаджети, мобільний інтернет), і сприятиме розвитку й удосконаленню якості та доступності освіти, зокрема україномовної.

Україна є державою, де проживають різні етнічні групи, зокрема в Південному регіоні України. Кожна етнічна група має своє історичне коріння, свої традиції, культуру, що зумовлює утворення полікультурного мовного середовища під час освітнього процесу [9, с. 250; 16; 17].

Тому, одним із важливих чинників удосконалення украӥномовної освіти в Південному регіоні Украӥни є поліетнічність українського суспільства, оскільки в закладах освіти України особам, які належать до національних меншин, державою гарантується право на здобуття дошкільної та початкової освіти, поряд із державною мовою, мовою відповідної національної меншини [5].

Мовою закладів освіти, науки, державних установ, громадських і політичних організацій, офіційно-ділового спілкування, художньої літератури, театру, преси, кіно і телебачення є літературна мова [6, с. 7]. Літературна мова - це унормована форма національної мови, яка використовується для спілкування в суспільстві. Поширення та розвиток літературної мови залежить від стану мовної політики в державі, освіти, культурних традицій народу [19, с. 200].

Лінгводидактика як наука досліджує загальні закономірності навчання мовам, специфіку змісту методів і засобів навчання певній мові залежно від дидактичної мети й завдань, характеру матеріалу, який вивчається, умов монолінгвізму (одномовності) чи білінгвізму (двомовності), етапу навчання та інтелектуально-мовного розвитку учнів [2, с. 195]. 
М. Пентилюк наголошує, що українська мова як рідна і державна в усіх типах середніх і вищих закладів освіти є загальнодидактичною та концептуальною засадою української лінгводидактики і є засобом формування й розвитку мовної особистості «людини, яка любить, знає і береже рідну мову, з повагою ставиться до неї як до мови нашої держави, володіє іï виражальними засобами, користується нею у своїй професійній діяльності й у повсякденному житті» [12, с. 124].

Як бачимо, серед інших чинників розвитку україномовної освіти є розвиток української лінгводидактики як науки, одним з головних завдань якої є розвиток мовної особистості.

Відповідно до ключових компетентностей Нової української школи, сучасні здобувачі освіти мають уміти спілкуватися державною, а в разі відмінності рідною мовами, усно і письмово висловлювати й тлумачити поняття, думки, почуття, факти та погляди, через слухання, говоріння, читання, письмо, застосування мультимедійних засобів; здатні реагувати мовними засобами на повний спектр соціальних і культурних явищ - у навчанні, на роботі, вдома, у вільний час, усвідомлювати роль ефективного спілкування.

Науковиці Г. Кацавець i Л. Паламар пов’язують культуру особистості 3 досконалим знанням української літературної мови, бездоганним опануванням ї стильовими тонкощами та умінням щоденно слугуватися ними. Рівень мовної культури особистості, наголошують науковці, залежить від правильності та точності висловлювання думки [6, с. 5].

Ще одним чинником удосконалення сучасної україномовної освіти є розвиток мовної та мовленнєвої культури особистості.

Т. Окуневич, порушуючи питання вдосконалення україномовного спілкування, висловлює думку, що вчитель, формуючи в учнів уміння і навички україномовного спілкування на уроках української мови, повинен «передбачити досягнення ними такого рівня комунікативної компетенції, який був би достатнім для здійснення спілкування у певних комунікативних сферах» [10, с. 123]. Як зазначає дослідниця, саме соціально-культурні і соціолінгвістичні знання, уміння і навички зумовлюють загальний розвиток особистості учня, а також його комунікативної компетенції, 
забезпечуючи входження в соціум і сприяючи соціалізації в новому суспільстві [10, c. 123].

Як бачимо, не менш важливим чинником розвитку україномовної освіти $\epsilon$ забезпечення освітнього прочесу науково-педагогічними працівниками відповідної кваліфікації, що можуть і повинні формувати у здобувачів освіти вміння й навички україномовного спілкування.

Задля вирішення вище зазначеного питання у системі післядипломної освіти Південного регіону України під час підвищення кваліфікації педпрацівників, зокрема у Комунальному вищому навчальному закладі «Херсонська академія неперервної освіти» Херсонської обласної ради, використовуються різні сучасні технології. Ними забезпечується «свідоме залучення педагога до розв'язання актуальної освітньої й соціокультурної проблематики; оволодіння ним сучасними знаннями та іншими інтелектуальними засобами; адекватний сучасній освітній ситуації професійний розвиток педагога; створення якісного продукту професійної діяльності (якість освіти учнів); розвиток внутрішнього потенціалу педагога» [4, с. 100].

О. Прокопова характеризує механізм творення комунікативної компетенції в наступній послідовності: мовна компетенція (знання засобів мови, одиниць і категорій усіх рівнів, а також правил, за якими будують мовні конструкції, й вміння такі правила застосовувати); мовленнєва компетенція (спроможність сприймати й розуміти висловлювання); комунікативна компетенція (здатність ефективно спілкуватися в різних умовах у ролі адресанта й адресата) [15, с. 55].

Комунікативна компетенція, як зазначає дослідниця, включає в себе: уміння людини спілкуватися з іншими людьми, доцільно використовуючи відповідні засоби рідної (української) мови в практиці, засоби виразності та ініціативні прояви. Вона також пропонує обов'язково використовувати на кожному занятті вправи, «спрямовані на очищення мовлення молодих українців від сумнозвісного суржику - явища, яке знижує якість не тільки мовлення, але й думки, адже мовленнєвий та мисленнєвий процеси взаємопов'язані» [15, с. 56].

Питання «очищення мовлення молодих українців від сумнозвісного суржику» у Південному регіоні України, через білінгвізм та поліетнічність, залишається достатньо актуальним. 
Висновки. Мова є явищем суспільним. Вербальна й невербальна комунікація між членами суспільства різного вікового цензу, різної статі, різних світоглядів, культур відбувається як на побутовому, так і на офіційному рівнях. Досягнення поставленої мети спілкування, взаєморозуміння між адресантом i адресатом безпосередньо залежить від комунікативних компетентностей. Такі навички успішного спілкування набуваються особою 3 досвідом у сімейно-родинному вихованні, у комунікаційному оточенні як ситуативному, так і довготривалому (друзі, знайомі, однолітки, колеги та інші), а також під час освітнього процесу в навчальних закладах.

Отже, одними з основних чинників розвитку сучасної україномовної освіти в Південному регіоні України, на нашу думку, є наступні, які можна поділити на три групи за основними напрямами суспільних відносин:

1. Соціально-політичні: реалізація державної освітньої та національної політики, що закріплено нормативно-правовою документацією, зміцнення основ розвитку українського суспільства i держави, становлення самодостатнього громадянина-патріота України. Ці чинники, їх змістовне наповнення безпосередньо залежать від чинного суспільно-політичного ладу та ідеологічного спрямування державної політики.

2. Соціально-економічні: науково-технічний прогрес, розвиток інформаційнокомунікативних технологій, зміцнення та поліпшення матеріально-технічної бази освітнього процесу й освітньої галузі зокрема. Ця група чинників зумовлюється економічним зростанням як кожним членом суспільства окремо, так і держави загалом.

3. Соціокультурні: поліетнічність української держави, полікультурне освітнє середовище, розвиток української лігводидактики, розвиток літературної української мовної системи, розвиток мовленнєво-комунікативних компетентностей особистості, іiі мовної культури, підготовка кваліфікованих науково-педагогічних працівників. Ця група чинників зумовлюється такими факторами, як двомовністю й поліетнічністю Південного регіону України, а також освітньою метою.

Таким чином, на розвиток україномовної освіти безпосередньо впливають усі вище зазначені чинники, що уможливлюють реалізацію державної політики України, направленої на вирішення мовного й освітнього питання, зокрема у Південному регіоні. 


\section{References}

1. Borysenko V. Y., Teleguz O. I. Natsionalna osvita $i$ formuvannya ukrainskoi modernoi natsii u 1921-1934 rokakh: yevropeiski tendentsii ta radianski realii [National education and the formation of the Ukrainian modern nation in 1921-1934: European trends and Soviet realities] : textbook, Kyiv, 2012. 156 p.

2. Goncharenko S. V. Ukrainskiy pedagogichniy slovnik [Ukrainian pedagogical dictionary]. Kyiv, 1997. 375 p.

3. Hrytsiak D. I. Mova iak obiekt derzhavnoi polityky, statusna i korpusna movna polityka [Language as an object of state policy, status and corpus language policy]. Derzhava i pravo, 2012. Issue 56. Pp. 649-654.

4. Zhorova I. Ya. Rozvytok shkilnoi humanitarnoi osvity : istorychnyi aspect [Development of school humanities education: historical aspect.]. Naukovyi chasopys. Seriia 5 : Pedahohichni nauky : realii ta perspektyvy : zb. nauk. prats. Kyiv : Vyd-vo NPU imeni M. P. Drahomanova, 2018. Issue 64. Pp. 89-92.

5. Zhorova I. Ya. Suchasni tehnolohii rozvytku profesionalizmu pedahohiv u systemi pisliadyplomnoi osvity Ukrainy [Modern technologies of professionalism development of teachers in the system of postgraduate education of Ukraine]. Visnyk Cherkaskoho universytetu. Pedahohichni nauky. 2019. No 1. Pp. 96-103.

6. Pro osvitu : Zakon Ukrayini vid 05 veresnia 2017 No 2145-VIII. [On Education: Law of Ukraine of September 5, 2017 No 2145-VIII. URL: https://zakon.rada.gov.ua/laws/show/2145-19

7. Katsavets G. M., Palamar L. M. Mova dilovikh paperiv: pidruchnik [The language of business papers: textbook]. 4 ed., revised and supplemented. Kyiv, 2008. 320 p.

8. Pro Vnesennia zmin do nakazu Ministerstva ocviti i nauki Ukrayini vid 16.06.2015 No. 641 : Nakaz MON Ukrayini vid 29 lypnia 2019. No 1038. [On amendments to the order of the Ministry of Education and Science of Ukraine dated 16.06.2015 No 641: Order of the Ministry of Education and Science of Ukraine dated 29 July 2019 No 1038.] URL: https://mon.gov.ua/ua/npa/pro-vnesennya-zmin-do-nakazu-ministerstva-osviti-i-nauki-ukrayinivid-16062015-641 (access date: 06.04.2020).

9. Odaynyk S. F. Upravlinnia navchalnim zakladom $v$ umovakh polikulturnogo osvitniogo seredovichshia [Management of an educational institution in a multicultural educational environment]. Pedagogical almanakh. 2015. Issue 25. Pp. 249-254.

10. Okunevych T. G. Formuvannia komunikativnoi kompetenzii uchniv zasobami ridnoi movy [Formation of communicative competence of students by means of native language]. Ped. science. 2016. May. No. 2 (53). Pp. 123-127.

11. Oleksenko V. P. Formuvannia dukhovnosti osobystosti zasobamy ridnoi movy [Formation of spirituality of the person by the means of native language]. Pedahohichni nauky. 2004. Issue XXXVI. Pp. 189-192.

12. Pentyliuk M. I. Rozvitok ukrainskoi lingvodidaktiki v konteksti Derzhstandartu bazovoi i povnoi serednioi osviti v Ukraini [Development of Ukrainian language didactics in 
the context of the State Standard of basic and complete secondary education in Ukraine]. Bulletin of Lviv University. Philological Series. 2010. No 50. Pp. 123-130.

13. Petko L. V. Vyklyky XXI stolittia dlia osvitnoho prostoru Ukrainy. Naukovi pratsi ChNU: nauk. zhurnal [The challenges of educational space in the $21-^{\text {st }}$ century]. Mykolaiv : Vydvo ChNU imeni Petra Mohyly, 2017. Issue 303. Vol. 291. Pp. 10-14.

14. Pet'ko L. V. Nacional'nyj komponent u formuvanni profesijno orijentovanogo inshomovnogo navchal'nogo seredovyshha $v$ umovah universytetu [National component in the way of forming professionally oriented educational environment in the conditions of university]. Naukovi zapysky Kyiv: Vyd-vo NPU imeni M. P. Dragomanova, 2014. Vol. CXVII (117). Pp. 125-135.

15. Prokopova O. P. Movlennievo-komunikatyvna kompetentnist iak odna iz skladovych profesiinoho stanovlennia fakhivtsia [Speech-communicative competence as one of the components of professional development of a specialist] : Zbirnyk naukovykh prats Kamianets-Podilskoho natsionalnoho universytetu imeni Ivana Ohiienka. Ser. Pedahohichna. 2010 No. 16. Pp. 54-57.

16. Sliusarenko N. V. Rol natsionalnoi kultury u formuvanni polikulturnoi osobystosti [The role of national culture in the formation of a multicultural personality] // II Dunaiski naukovi chytannia: dukhovno-tvorcha konstanta osobystosti : materialy mizhnar. nauk.-prakt. konf., prysv. 60-richchiu pedahohichnoho fak-tu Izmailskoho derzh. humanitarnoho un-tu (23 veresnia 2016 roku, m. Izmail) : v 2 t. Izmail : RVV IDHU ; «SMYL», 2016. Issue 2. Pp. $72-74$.

17. Sliusarenko N. V. Teoretychni osnovy polikulturnoho vykhovannia shkoliariv [Theoretical foundations of multicultural education of schoolchildren]. Tavriiskyi visnyk osvity. 2011. No 2. Pp. 30-35.

18. Слюсаренко Н. В. Теоретичні основи полікультурного виховання школярів. Таврійський вісник освіти. 2011. № 2. С. 30-35.

19. Spirin O. M. Metodologichni zasadi rozvitku suchasnikh sistem vishchoi osviti [Methodological principles of development of modern systems of higher education]. Bulletin of Zhytomyr State University named after Ivan Franko. 2005. Pp. 104-109. URL: http://eprints.zu.edu.ua/407/2/3C40E1CE.pdf (access date: 06.04.2020).

20. Ukrainska mova. Entsiklopediia [Ukrainian language. Encyclopedia]: za redakzieiu Muromtseva I. V. Kyiv, 2011. 400 p.

21. Pet'ko L. Priorities for the development of the Ukrainian national idea and the upbringing students of this modern era. Intellectual Archive. Toronto : Shiny Word.Corp. (Canada), 2017. Vol. 6. No. 5, September/October. Pp. 59-78.

Translation of the Title, Abstract and References to the Author's Language

УДК 373.5.016:811.161.2(477.7)»1920/1938»(043.3)

Сушко Володимир. Основні чинники розвитку сучасної україномовної освіти в Південному регіоні України. 
У статті розглянуто питання розвитку сучасної україномовної освіти в Південному регіоні України й визначено основні його чинники. Серед яких $\epsilon$ зміцнення основ розвитку українського суспільства i держави, становлення самодостатнього громадянина-патріота України, удосконалення комунікативних компетентностей; розвиток інформаційно-комунікативних технологій, економічні перетворення в Україні, розвиток, зміцнення та поліпшення матеріально-технічної бази освітньої галузі; поліетнічність української держави, полікультурне освітнє середовище, розвиток української лігводидактики, розвиток мовленнєвокомунікативних компетентностей особистості, iї мовної культури, підготовка кваліфікованих науково-педагогічних працівників. Автором зроблено висновок, що на розвиток україномовної освіти безпосередньо впливають усі вище зазначені чинники, що уможливлюють досягнення й реалізацію одного з основних завдань національної мовної й освітньої політики України, такого як удосконалення комунікативних компетентностей мовної особистості.

Ключові слова: білінгвізм, комунікативна компетентність, мовна особистість, мовна політика, національна політика, поліетнічність, реформування освіти, освітня політика, україномо8вна освіта.

\section{Jimepamypa}

1. Борисенко В. Й, Телегуз О. І. Національна освіта і формування української модерної нації у 1921-1934 роках: європейські тенденції та радянські реалії : навч. посібник. Київ, 2012. 156 с.

2. Гончаренко С. У. Український педагогічний словник. Київ, 1997. 375 с.

3. Грицяк Д. І. Мова як об’єкт державної політики, статусна і корпусна мовна політика. Держсава і право, 2012. Вип. 56. С. 649-654.

4. Жорова І. Я. Розвиток шкільної гуманітарної освіти : історичний аспект. Науковий часопис Національного педагогічного університету імені М. П. Драгоманова. Серія 5 : Педагогічні науки : реалії та перспективи : зб. наук. праць. Київ : Вид-во НПУ імені М. П. Драгоманова, 2018. Вип. 64. С. 89-92.

5. Жорова І. Я. Сучасні технології розвитку професіоналізму педагогів у системі післядипломної освіти України. Вісник Черкаського університету. Педагогічні науки. 2019. Вип. № 1. С. 96-103.

6. Про освіту : Закон України від 05 вер. 2017 p. № 2145-VIII. URL : https://zakon.rada.gov.ua/laws/show/2145-19 (дата звернення: 12.04.2020).

7. Кацавець Г. М., Паламар JI. М. Мова ділових паперів : підручник. 4-те вид., перероб. і доп. Київ, 2008. 320 с.

8. Про внесення змін до наказу Міністерства освіти і науки України від 16.06.2015 № 641 : Наказ $\mathrm{MOH}$ України від 29 липн., 2019 p. № 1038. URL: https://mon.gov.ua/ua/npa/pro-vnesennya-zmin-do-nakazu-ministerstva-osviti-i-naukiukrayini-vid-16062015-641 (дата звернення: 06.04.2020).

9. Одайник С. Ф. Управління навчальним закладом в умовах полікультурного освітнього середовища. Педагогічний альманах. 2015. Вип. 25. С. 249-254. 
10. Окуневич Т. Г. Формування комунікативної компетенції учнів засобами рідної мови. Науковий вісник МНУ ім. В. О. Сухомлинського. Пед. науки. 2016. Травень. № 2 (53). С. $123-127$.

11. Олексенко В. П. Формування духовності особистості засобами рідної мови. Педагогічні науки. 2004. Вип. XXXVI. С. 189-192.

12. Пентилюк M. I. Розвиток української лінгводидактики в контексті Держстандарту базової і повної середньої освіти в Україні. Вісник Львівського університету. Сер. Філологічна. 2010. № 50. С. 123-130.

13. Петько Л. В. Виклики XXI століття для освітнього простору України. Наукові пращі [Чорноморського державного університету імені Петра Могили комплексу "Києво-Могилянська академія"]. Серія : Педагогіка : наук. журн. / Чорном. держ. ун-т імені Петра Могили; ред. кол. : О. П. Мещанінов (голова) [та ін.]. Миколаїв : Вид-во ЧНУ імені Петра Могили, 2017. Т. 303. Вип. 291. С. 10-14.

14. Петько Л. В. Національний компонент у формуванні професійно орієнтованого іншомовного навчального середовища в умовах університету. Наукові записки : [збірник наукових статей] / М-во освіти і науки України, Нац. пед. ун-т імені М.П.Драгоманова ; укл. Л. Л. Макаренко. Київ : Вид-во НПУ імені М. П. Драгоманова, 2014. Випуск CXVII (117). С. 125-135. URI :

http://enpuir.npu.edu.ua/handle/123456789/7830

15. Прокопова О. П. Мовленнєво-комунікативна компетентність як одна із складових професійного становлення фахівця. Збірник наукових працьь Кам'янецьПодільського національного університету імені Івана Огієнка. Сер. Педагогічна. 2010. № 16. C. 54-57.

16. Слюсаренко Н. В. Роль національної культури у формуванні полікультурної особистості // II Дунайські наукові читання: духовно-творча константа особистості : матеріали міжнар. наук.-практ. конф., присв. 60-річчю педагогічного фак-ту Ізмаїльського держ. гуманітарного ун-ту (23 вересня 2016 року, м. Ізмаїл) : в 2 т. Ізмаїл : РВВ ІДГУ ; «СМИЛ», 2016. Т. 2. С. 72-74.

17. Слюсаренко Н. В. Теоретичні основи полікультурного виховання школярів. Таврійський вісник освіти. 2011. № 2. С. 30-35.

18. Спірін О. М. Методологічні засади розвитку сучасних систем вищої освіти. Вісник Житомирського державного університету ім. Івана Франка. 2005. C. 104-109. URL: http://eprints.zu.edu.ua/407/2/3C40E1CE.pdf (дата звернення: 06.04.2020).

19. Українська мова. Енциклопедія : за ред. І. В. Муромцева. Київ, 2011. 400 с.

20. Pet'ko L. Priorities for the development of the Ukrainian national idea and the upbringing students of this modern era. Intellectual Archive. Toronto : Shiny Word.Corp. (Canada), 2017. Vol. 6. No. 5, September/October. Pp. 59-78. 